Proc. Estonian Acad. Sci. Eng., 2002, 8, 2, 68-83

\title{
Investigations of prestressed cable structures at Tallinn Technical University
}

\author{
Valdek Kulbach \\ Department of Structural Design, Tallinn Technical University, Ehitajate tee 5, 19086 Tallinn, \\ Estonia; vkulbach@edu.ttu.ee \\ Received 8 February 2002, in revised form 1 April 2002
}

\begin{abstract}
The paper presents a summary of research activities of the Department of Structural Design at TTU in the field of suspension structures against the background of the world developments in this field.
\end{abstract}

Key words: cable, cable network, girder-stiffened structure, hanging roof, hypar-network.

\section{INTRODUCTION}

The modern era of suspension bridges has lasted for nearly two centuries while the first contemporary suspension roof structures appeared only about 50 years ago. Investigation of suspension structures at TTU began in the end of 1950s. The methods elaborated for the calculation of different suspension structures are based on general equations for the determination of relative displacements, taking into account actual boundary conditions. Suitability of using hypar-networks inside an elliptical contour beam, lying on three or four plane supports which permit free deformation of the contour beam in horizontal directions, has been verified.

Some outstanding prestressed suspension structures will be analysed below. The main attention is paid to girder-stiffened suspension bridges and plain and spatial suspension roof structures, prestressed by means of contact loads between the carrying and the stretching cables. The references include a number of proceedings of international conferences devoted to the problems of suspension roof and bridge structures. Historical development of suspension bridges is illustrated by a diagram demonstrating the increase of the covered spans. The drawings of some outstanding bridge and roof structures are presented. 
Description of the cable networks for the acoustic screens erected in Estonia is illustrated by their schematic drawings. The problems related to the design of the self-anchored suspension bridge for the strait crossing to the Saaremaa Island are discussed.

\section{DEVELOPMENT OF LONG-SPAN CABLE SUPPORTED BRIDGES AND SUSPENSION ROOFS}

Erection of the Menai bridge in UK in the 1830s with a span of 177 m may be considered as the beginning of the modern era of design and construction of suspension bridges. Development of bridge building continued mainly in the USA. The $1000 \mathrm{~m}$ boundary was exceeded by George Washington bridge with the span of $1067 \mathrm{~m}$ in 1931. In 1981 the Humber bridge in UK (span $1410 \mathrm{~m}$ ) and in 1998 the East bridge over the Great Belt in Denmark (span $1624 \mathrm{~m}$ ) became record-makers. In the 1990s the main arena of construction of long span bridges went over to Asia. Bridges with the main span over $1000 \mathrm{~m}$ may be mentioned as examples: Tsing Ma in Hong Kong, Yangtse in China, and Kudos Kurushima in Japan. The span record with 1990 m belongs to Akashi Kaikyo bridge in Japan (Fig. 1) which was opened in 1999. Development of record span suspension bridges is illustrated by a diagram in Fig. 2. Erection of cable-stayed bridges has a shorter history than of the suspension ones. Some prominent samples belong to the 1950s; in the following decades symmetrical and nonsymmetrical cable-stayed bridges became very popular. The bridges with the longest span $(856 \mathrm{~m})$ were erected in the 1990s in France (Normandia bridge) and Japan (Tatara bridge, $890 \mathrm{~m}$ ). Self-anchored suspension bridges combine the advantages of suspension and cable-stayed bridges.

Erection of suspension structures for roofs has a 50 years history. Most popular types of suspension roof structures are: 1) prestressed truss-type plane structures, 2) prestressed structures with doubled radial cables inside of a circular or elliptical contour beam, and 3) saddle-formed prestressed cable networks with closed contour structures. The first contemporary suspension roof structures were

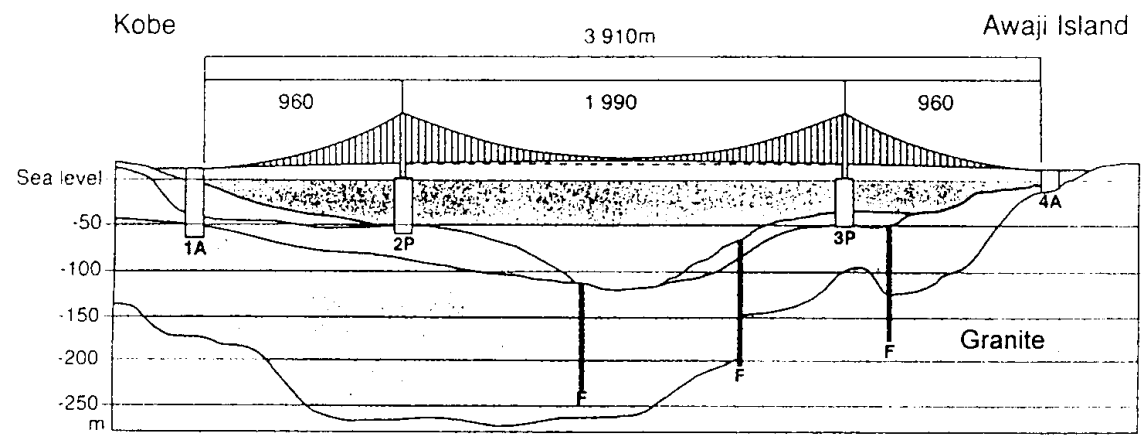

Fig. 1. Schema of the Akashi Kaikyo bridge in Japan. 


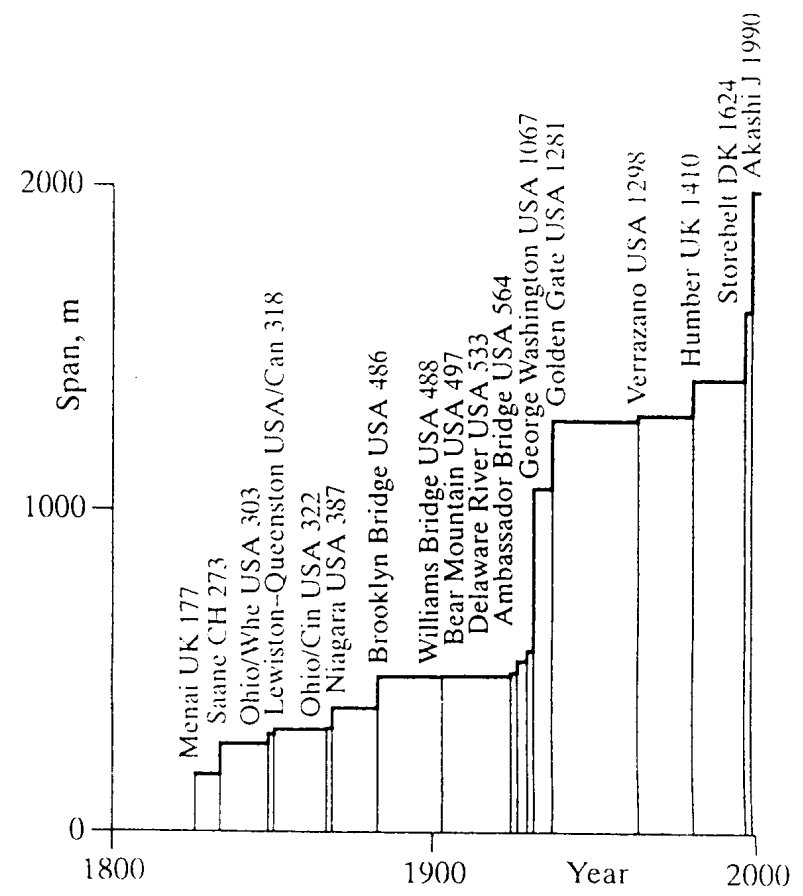

Fig. 2. Record span suspension bridges.

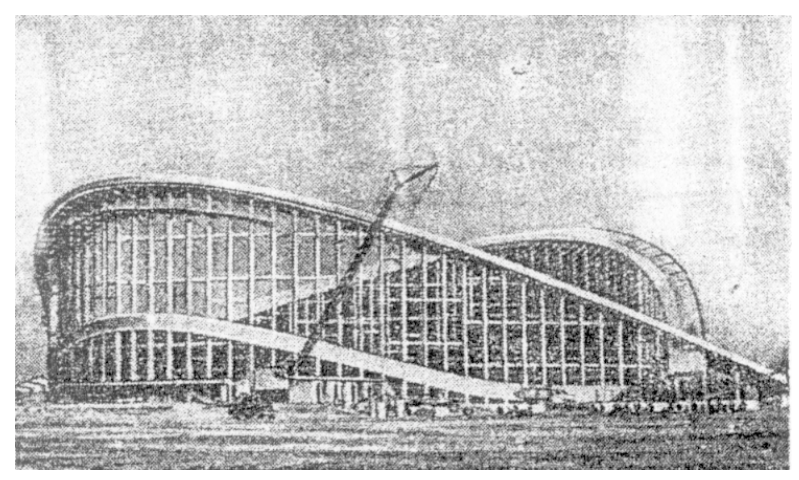

Fig. 3. Saddle-shaped roof of the Raleigh Arena, USA.

built in 1950s. The best known of them is the saddle-shaped roof for the Raleigh Arena in the USA (Fig. 3). In the 1950s a number of roofs with cable-anchored suspension trusses and with radial cables were also built.

Experience of suspension structures obtained in Estonia includes special types of roof networks and a few suspension bridges with relatively small spans. Two cable networks were built as acoustic screen structures with timber coverings for song festival tribunes. The first of them was erected in 1960 in Tallinn as a 
network inside the inclined contour beam of two plane arches, supported by massive counterforts (Fig. 4). The second one, erected in 1994 in Tartu, is an inclined hypar-network with an elliptical contour beam (Fig. 5). The contour beam lies on three plane supports, enabling its free deformation in horizontal directions. The historical suspension footbridge in Viljandi was reconstructed in the 1990s by means of a replacement of the handrails by truss-beams (Fig. 6). New suspension bridges with spans of 60 and 50 m were erected in Võru (1998) and Kurgja (2001).

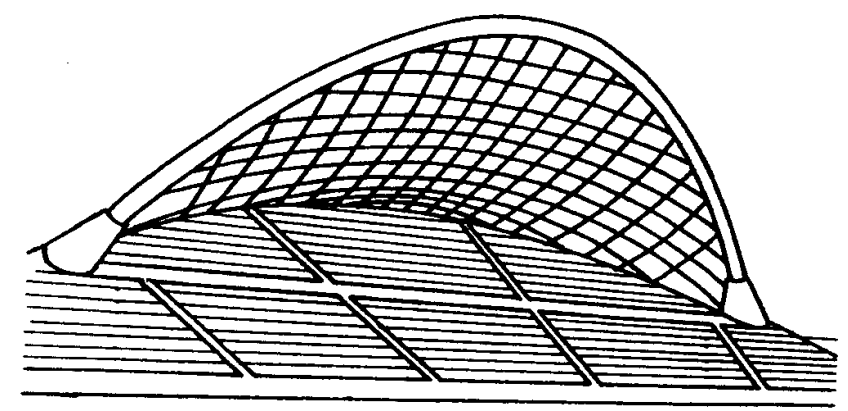

Fig. 4. Schema of the Tallinn song festival tribune.

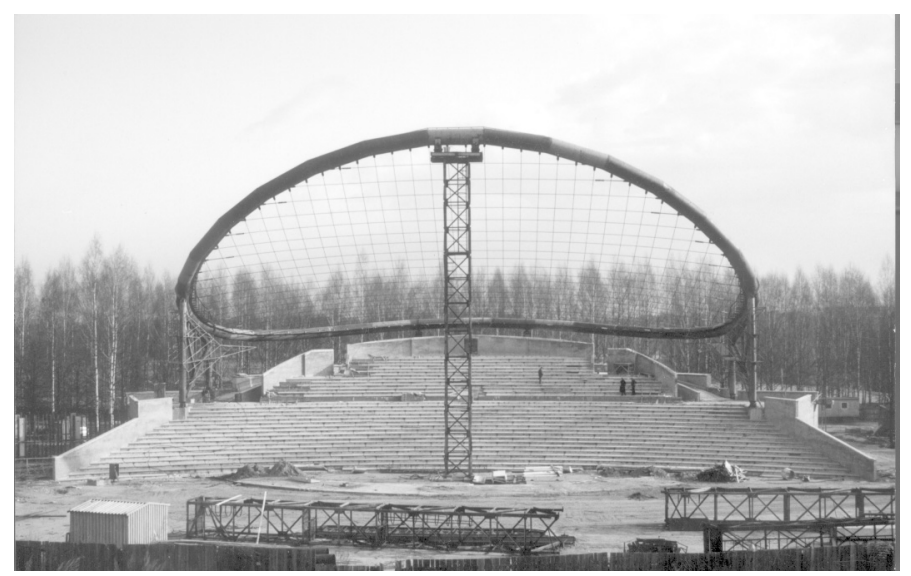

Fig. 5. Erection of the song festival tribune in Tartu. 


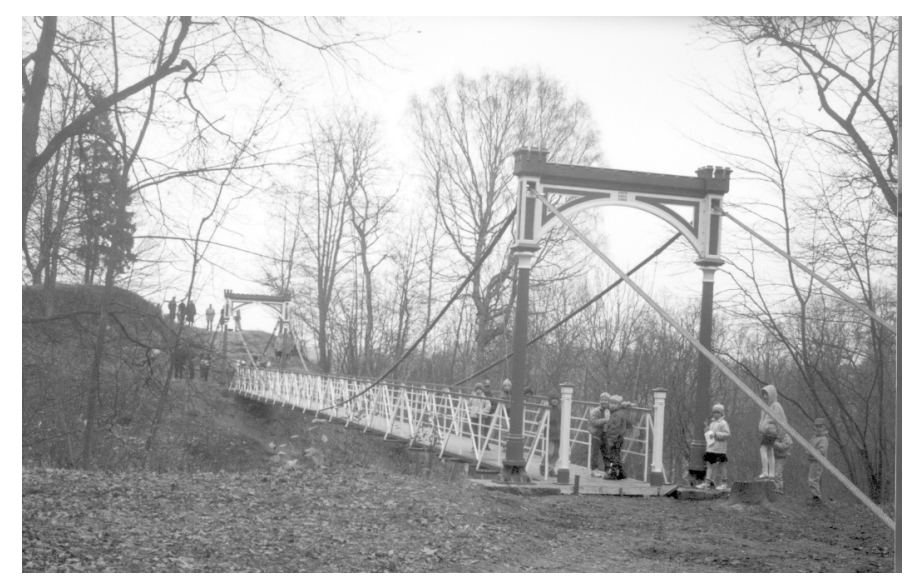

Fig. 6. Suspension footbridge in Viljandi.

\section{A REVIEW OF INTERNATIONAL EXPERIENCE OF CABLE STRUCTURE ANALYSIS}

The equations for elastic or rigid cables have been used as the basis for calculation of suspension structures. Suspension bridges with a stiffening girder were usually calculated as statically indeterminate structures. For solving the problem of the behaviour of a geometrically non-linear model, a cubic equation relative to the horizontal cable force was often used. Transferring the equations to prestressed compound structures led to very complicated calculation models. First remarkable works for calculation of different cable systems were published in the $1950 \mathrm{~s}\left[{ }^{1-3}\right]$. Some monographs were published in the $1960 \mathrm{~s}\left[{ }^{4-10}\right]$. A number of conference reports about suspension structures were published in different proceedings and collections $\left[{ }^{11-22}\right]$. A summary of the main studies, dealing with the analysis of suspension structures before 1960s, is presented in $[7]$. It is worth to mention that the methods of analysis, presented in this monograph, are complicated and difficult to use. No attention was paid to the problem of interaction of the network and the contour beam. In spite of that, the description of different suspension structures and their behaviour is of great interest.

In the field of spatial suspension roof structures, several publications deal with the determination of the initial form of the network $\left[^{8,10,23}\right]$. However, we have found some inaccuracies in the postulates used. For instance, the assumptions about the coincidence of the cable form with the geodetic lines of the chosen roof surface or about determination of the roof surface by equations of a membrane or as minimum surfaces, are not correct.

In the 1970s and 1980s a number of conferences, devoted to suspension roof structures, were organized by the International Association for Shell and Spatial 
Structures and other organizations $\left[{ }^{16-20}\right]$. Much attention was paid to prestressed suspension networks $\left[{ }^{24-28}\right]$. During the last decades of the 20th century an extensive erection of long-span cable-stayed and suspension bridges took place, especially in Japan and other Asian countries. A number of international conferences dealing with problems of bridge design and construction were organized $\left[{ }^{21,22}\right]$. The topics were primarily related to the description of erected structures; in the field of calculations the finite element method predominated. In these conferences much attention was paid to long-span bridges, erected in Asian countries, Denmark, and Korea.

Let us mention also interesting papers devoted to different problems related to suspension structures $\left[{ }^{29-35}\right]$.

\section{STUDIES OF PRESTRESSED CABLE STRUCTURES AT TTU}

Investigations of suspension structures at TTU were provoked by the problems of design and erection of the acoustic screen for the song festival stage in Tallinn in the period $1958-1960\left[{ }^{36-38}\right]$. The list of publications up to 1982 is presented in the booklet $\left[{ }^{39}\right]$. This booklet includes 105 publications in the field of suspension roof structures. The main attention was paid to different saddle-formed suspension structures $\left[^{40-52}\right]$. Problems of determination of the initial form of networks were also studied $\left[{ }^{53,54}\right]$. Some problems of dynamic behaviour of structures were discussed in $\left[{ }^{55-57}\right]$. Both continuous and discrete calculation models were used. Continuous modelling was mainly applied to hypar-networks with elliptical contour beams. It was proved that a simple approximation of the deflection function gives results, very close to the exact ones. For the case of one-side snow loading, dividing of the total load into symmetrical and antisymmetrical parts with successive calculation under these loads was recommended. In this regard the possibility and conditions for application of the principle of superposition of stresses for geometrically non-linear systems was verified $\left[{ }^{58}\right]$. Specific features of these investigations are presenting of the basic equations with the relative deflection as an unknown and consideration of the displacements of the contour beam. Besides theoretical investigations, a lot of attention has been paid to experimental investigations on great scale models (Figs. 7 and 8).

Together with the hypar-networks, the behaviour of a single cable has also been determined by a cubic equation regarding the relative deflection $\left[{ }^{59}\right]$.

Relative deflection of the cable $\zeta_{0}=w_{0} / f$ for all load cases may be determined from the cubic equation

$$
\zeta_{0}^{3}+3 \zeta_{0}^{2}+\left(2+p_{0}^{*}\right) \zeta_{0}=p^{*}
$$

where $p^{*}$ is the loading factor shown in Table $1, p_{0}^{*}=p^{*} p_{0} / p$ is initial loading factor, $p_{0}$ and $p$ are initial and additional loads of the cable, respectively.

Deflection forms and inner forces of cables for different loading schemas are presented in Table 1. 


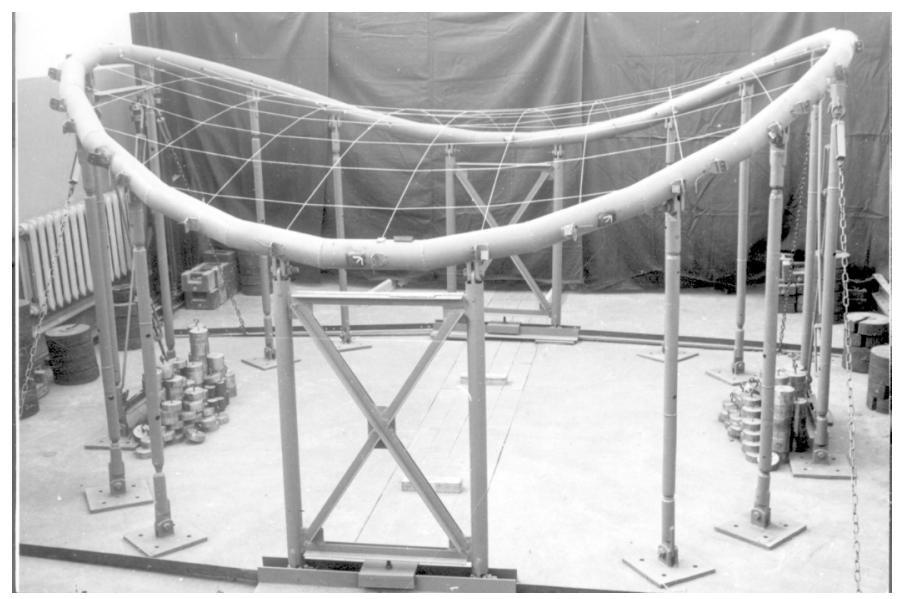

Fig. 7. Model of a hypar-network with elliptical layout.

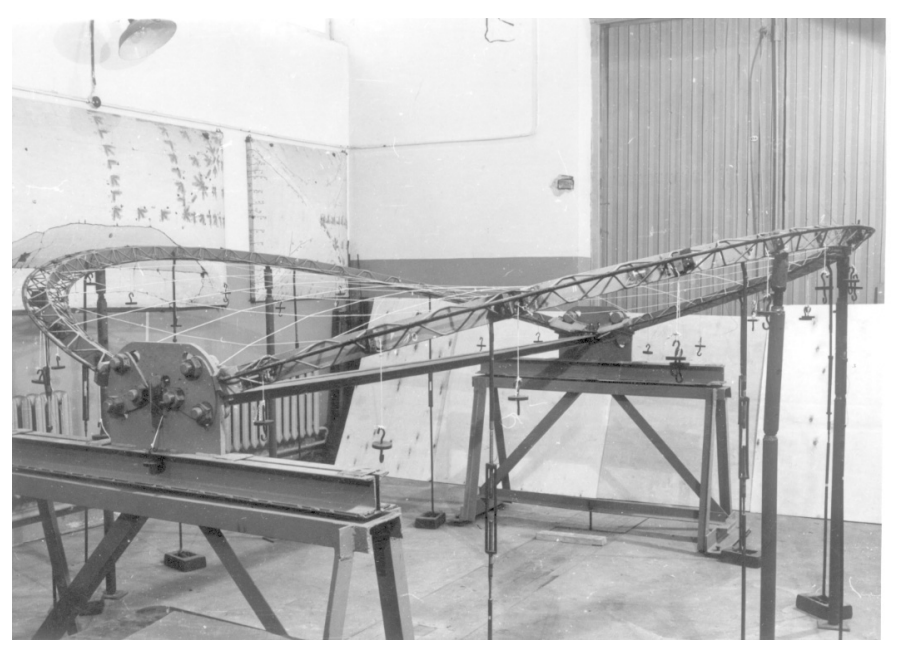

Fig. 8. Model of a cable network surrounded by two plane arches.

Later the method of continuous analysis was adapted for the calculation of prestressed cable-stiffened structures $\left[{ }^{60}\right]$, cable-stayed mast cranes $\left[{ }^{61,62}\right]$, and girder-stiffened cable structures $\left[{ }^{63}\right]$. For suspension bridges, the cases both with straight and loaded anchor cables have been investigated $\left[{ }^{64,65}\right]$. Several publications deal with self-anchored bridges $\left[{ }^{66,67}\right]$. A new method for discrete analysis of suspension bridges was presented in $\left[{ }^{68}\right]$. The formulae for cable-stiffened structures were also adapted for the suspension roof structures with radial cables $\left[{ }^{69,70}\right]$. Unified equations for the determination of deflections and inner forces in different cable structures are presented in Table 2. 


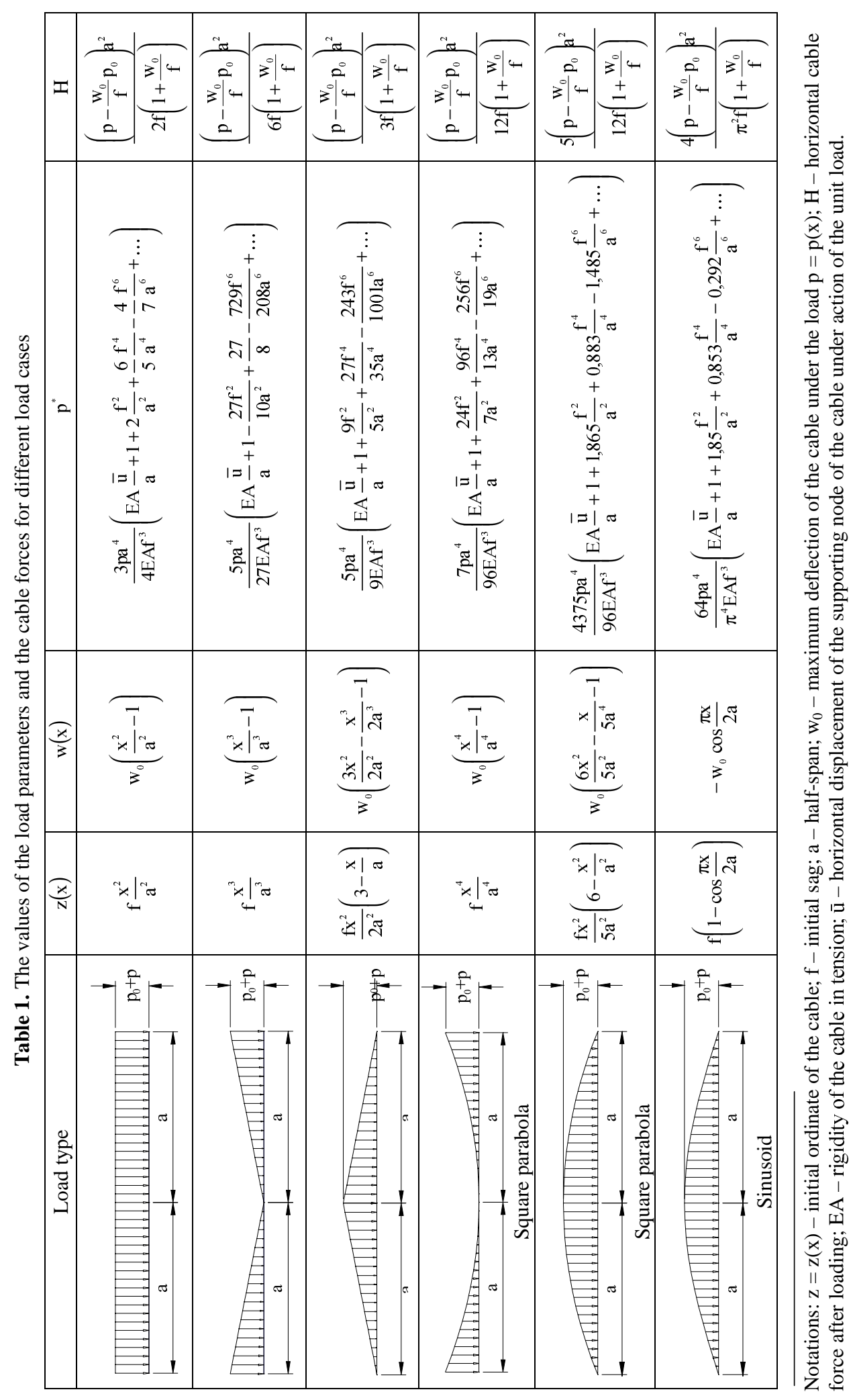




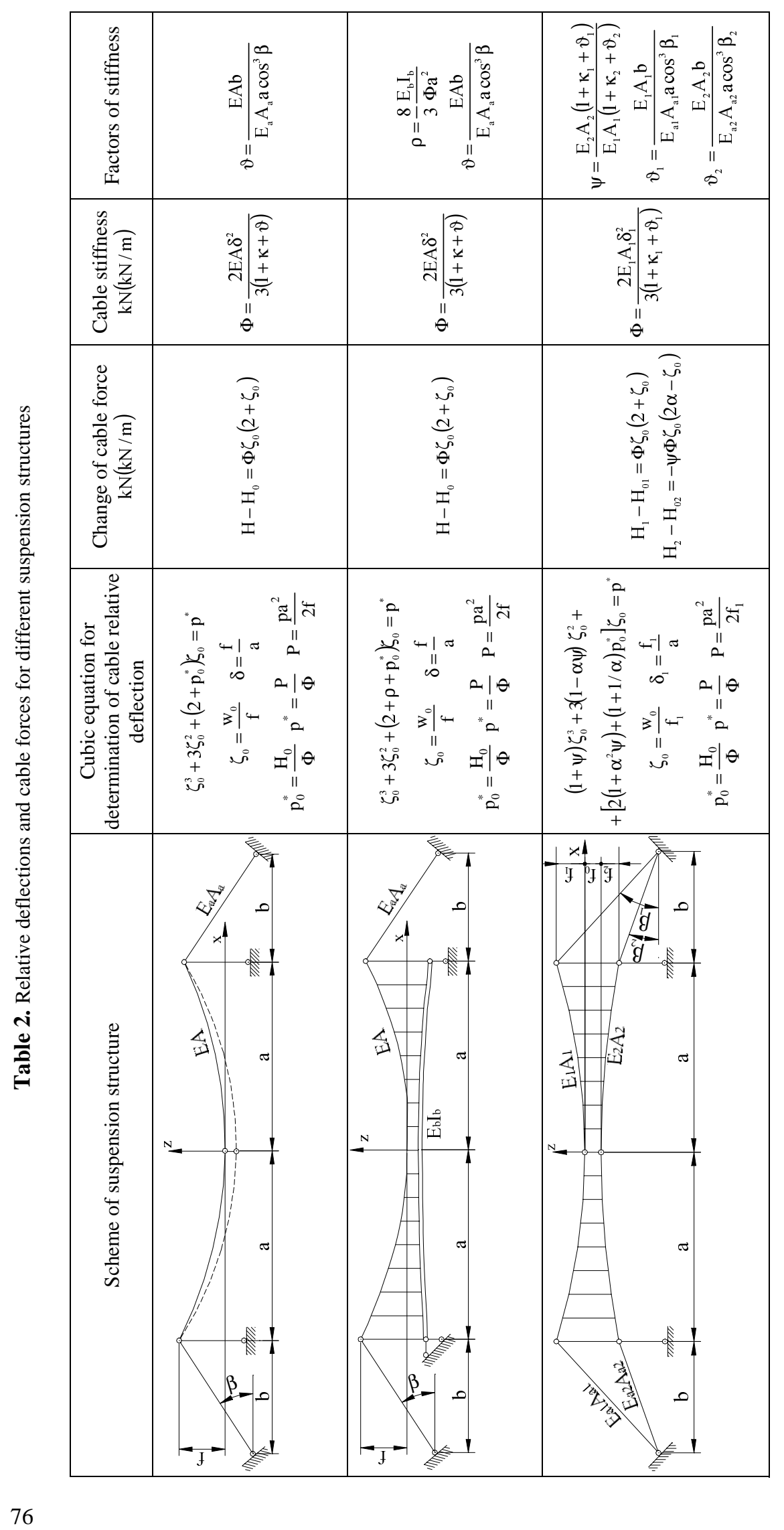




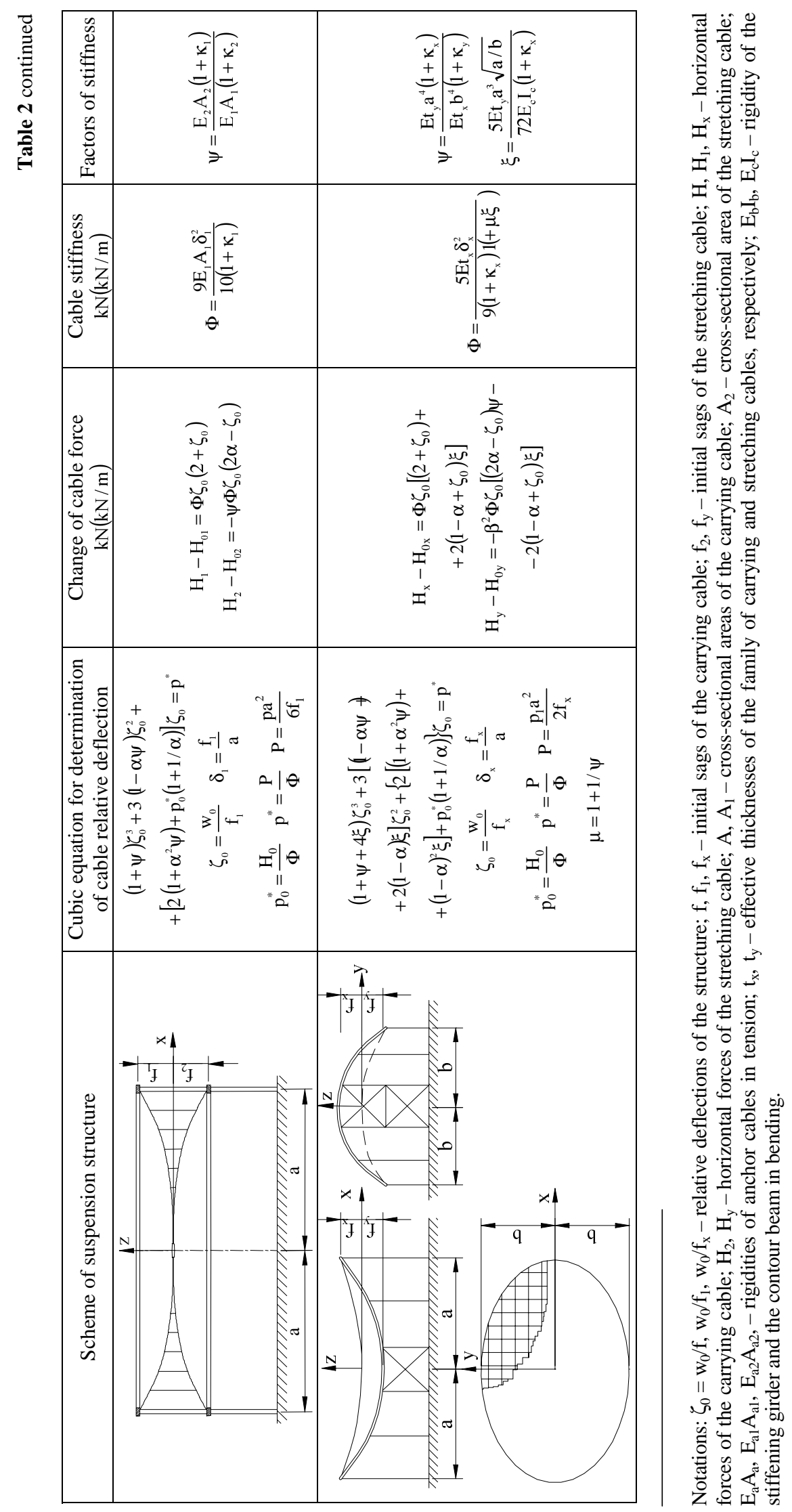


Application of discrete analysis to prestressed cable networks was based on spatial vector diagrams for the initial and loaded states. Main attention was paid to structures prestressed in conditions of free mutual sliding of the cables (selfformed network) and to orthogonal networks. The initial form for the latter may be found from a system of linear equations regarding the nodal ordinates. Discrete analysis of a self-formed network under the action of external loads leads to a system of non-linear equations, consisting of three conditions of equilibrium and two conditions of deformation compatibility of cable sections for every node of the network. The system of equations for an orthogonal network under the action of vertical loads consists of a condition of equilibrium for every node and an equation of deformation compatibility for every cable. Displacements of contour nodes of the network are taken into account in the equations of deformation compatibility. It is worth to mention that the system of discrete equations derived for an orthogonal network may be also obtained by means of application of the method of finite differences to the differential equations for continuous analysis of the network.

Besides publications cited above, research results in the field of different cable structures are presented also in $\left[{ }^{71-83}\right]$.

\section{ON THE FUTURE DEVELOPMENT OF SUSPENSION STRUCTURES}

The main trend of bridge development is further enlargement of spans. Spans of cable-stayed bridges increase over $1000 \mathrm{~m}$. In the field of suspension bridges preliminary proposals of spans up to 3000 and even $5000 \mathrm{~m}$ have been considered. As examples, fixed links between the Sicilia Island and the Peninsula of Apennines (the main span about $3000 \mathrm{~m}$ ), between Gibraltar and Marocco (main spans $3 \times 3500$ or $2 \times 5000 \mathrm{~m}$ ) and across the Strait of Bering (a number of spans about $5000 \mathrm{~m}$ ) may be mentioned. In case of extremely long spans, combination of suspension cables and stay-cables at the pylons and also spatial structures for pylons have been recommended. Dynamic behaviour may become a serious problem for super-span bridges. To increase the lateral rigidity, the Vformed pylons may be used. Recommendations for constructing the stiffening girder in two parallel streamline parts (twin-box cross-section) have been made. For spans over $3000 \mathrm{~m}$, the weight of the suspension cables may exceed the weight of the stiffening girder. Therefore the use of the hybrid cable system, composed of synthetics and steel, may serve the purpose.

As for the roofs of buildings, usually spans up to $200 \mathrm{~m}$ or roof diameters of 200 to $300 \mathrm{~m}$ satisfy present needs for assembly or sports halls. The main attention is to be paid to the effective interaction between the cable system and the supporting structures. Collation of different network structures demonstrates remarkable advantages of hypar-forms: even distribution of network deflections and inner forces, small required prestressing forces, and small bending moments of the contour beam. 


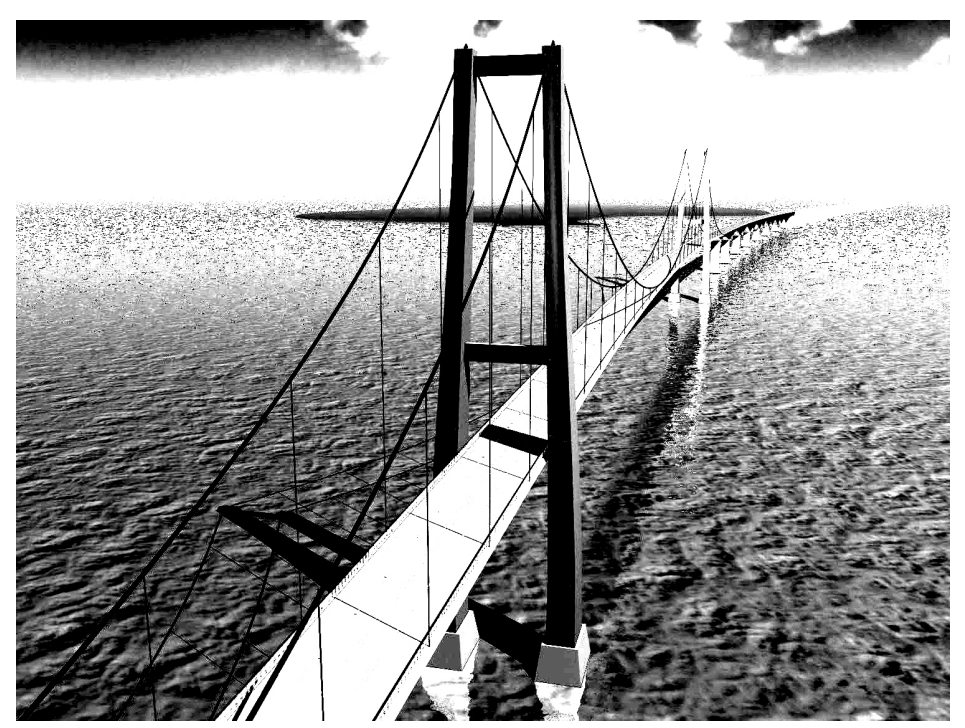

Fig. 9. Elevation of the supposed suspension structure of the bridge between Estonian mainland and the Saaremaa Island.

In connection with the preliminary design of the fixed link between the Saaremaa Island and the Estonian mainland, erection of a self-anchored suspension bridge for the navigable span of the crossing is being considered. The main issue is the stability of the bended and compressed stiffening girder. Both theoretical $\left[{ }^{67}\right]$ and experimental $\left[{ }^{84}\right]$ investigations have demonstrated sufficient stability of the relatively slender stiffening girder and have also shown advantages of the selfanchored structure with straight anchor cables. An elevation of the suspension structure for the main span of the supposed bridge is presented in Fig. 9. Economical comparison of different bridge structures for the navigable and approach spans is a task of the near future.

\section{REFERENCES}

1. Otto, F. Das hängende Dach. Bauweltverlag, Berlin, 1954.

2. Bandel, H. K. Betrachtungen über die Hängedach-Konstruktionen. Bauing., 1958, 33, 221-225.

3. Fritz, B. Von biegesteifen Fachwerksystem zum spannsteifen Seil- oder Stabhängewerk. Bauing., 1958, 33, 209-212.

4. Schleyer, F. K. Über die Berechnung von Seilnetzen. Techn. Univ. Berlin, 1960.

5. Katshurin, V. K. Theory of Suspension Systems. Strojizdat, Moscow, 1962 (in Russian).

6. Sobotka, Z. Suspended Roofs. Strojizdat, Moscow, 1964 (in Russian).

7. Otto, F. and Schleyer, F. K. Zugbeanspruchte Konstruktionen. Verlag F. Otto, Berlin, 1966.

8. Eras, G. and Elze, H. Über die Geometrie vorgespannter Seilnetzwerke. Deutsche Bauakademie, Berlin, 1966.

9. Dmitrijev, L. G. and Kasilov, A. V. Cable Roofs. Budivelnik, Kiev, 1968 (in Russian). 
10. Kuznetsov, E. N. Introduction to the Theory of Cable Systems. Strojizdat, Moscow, 1969 (in Russian).

11. Proc. International Conference "Hanging Roofs" (Rabinovitsh, M., ed.). Moscow, 1962 (in Russian), Wiesbaden, Berlin, 1966 (in German).

12. Proc. Symposium on the High-rise and Long-span Structures. Tokyo, 1964.

13. Proc. II International Conference on Prestressed Metal Structures. Praha, 1966.

14. Proc. Symposium on Problems of Large-span Shells. Leningrad, 1966.

15. Proc. International Conference on Space Structures (University of Surrey, 1966). Oxford, 1967.

16. Proc. III International Conference on Prestressed Metal Structures. Leningrad, 1971.

17. Proc. International Conference on Lightweight Shell and Spatial Structures. Alma-Ata, 1977.

18. Proc. World Congress on Shell and Spatial Structures. Madrid, 1979.

19. Proc. International Conference on Space Structures. Essex, UK, 1984.

20. Proc. IABSE Symposium on Long-span and High-rise Structures. IABSE Reports, Vol. 79, Tokyo, 1998.

21. Proc. IABSE Conference Seoul 2001. Cable-supported Bridges - Challenging Technical Limits. IABSE Reports, Vol. 84, Seoul, 2001.

22. Proc. International Cconference "Strait Crossings 2001". Bergen, 2001.

23. Bartlova, A. The analysis of non-loaded prestressed cable network. Stavebnicky Casopis, 1964, XII, 215-229.

24. Tottenham, H. and Williams, P.-G. Cable-net. Continuous system of analysis. J. Eng. Mech. Div., ASCE, 1970, 96, 277-293.

25. Buchholdt, H.-A. Tension structures. Struct. Eng., 1970, 48, 45-54.

26. Argyris, J. H. and Scharpf, D. W. Large deflection analysis of prestressed networks. J. Struct. Div., ASCE, 1972, 98, 633-654.

27. Gero, S. A design method for cable network structures. In Proc. IASS Conference. Alma-Ata, 1977, 84-94.

28. Moskaljov, N. S. Analysis of roof structures for a swimming pool. Building Mech. Struct. Eng. (Moscow), 1980, No. 4, 16-19 (in Russian).

29. Leonhardt, F. Zur Entwicklung aerodynamisch stabiler Hängebrücken. Die Bautechnik, 1968, No. $10,325-336$

30. Swan, R. Paradox defined (Akashi Kaikyo). Bridge Design and Eng., 1977, 9, 60-68.

31. Ban, S., Tsubota, H., Motohashi, S., and Yoshida, S. Suspended roof for the olympic skating arena, Nagano. Struct. Eng. Internat., 1998, 8, 187-188.

32. Peterson, A. Visual impact (Storebaelt Project). Bridge Design and Eng., 1998, 11, 47-53.

33. Jorgensen, G.-R., Petersen, A., and Pettersson, L. Hoga Kusten bridge, Sweden. Struct. Eng. Internat., 1999, 9, 106-108.

34. Clark, J. Triple-jump triumph (The Kurushima Kaikyo bridges). Bridge Design and Eng., 1999, 15, 27-31.

35. Cho, C.-Y., Lee, S.-W., and Park, S.-Y. Yongjong self-anchored suspension bridge. Struct. Eng. Internat., 2001, 11, 21-23.

36. Kulbach, V. Investigation of behaviour of the hanging roof for song festival tribune Tallinn. In Theses of Reports of Scientific Conference on Metal Structures. Moscow, 1961, 84-86 (in Russian).

37. Kulbach, V. and Laul, H. Experience of modelling and testing of hanging roof for song festival tribune Tallinn. In Reports of the Discussion on Investigation and Realization of Suspension Roofs. Moscow, 1962, 204-208 (in Russian).

38. Kulbach, V. and Laul, H. Concert shell in Tallinn. In Proc. IASS Congress on the Problems of Interdependence between Design and Erection of Shells for Industrial and Public Buildings (Leningrad, 1966). Moscow, 1968, 2, 359-368 (in Russian).

39. Kulbach, V. and Eek, D. Thin-walled and spatial structures. In Bibliography of Publications of the Department of Structural Engineering at TPI. Tallinn, 1983 (in Russian).

40. Kulbach, V. Analysis of flat shells of negative curvature resisting only to tension. Eesti NSV Tead. Akad. Toim. Fü̈s.-matem. tehn., 1965, 14, 406-413. 
41. Kulbach, V. Berechnung von Hängedächern mit negativer Krümmung als Schalen, die nur Zugwiderstand aufweisen. In Proc. II International Conference on Prestressed Metal Structures. Prague, 1966, 475-483.

42. Kulbach, V. and Ravasoo, A. Analysis of saddle-formed suspension roofs by method of collocation. Trans. Tallinn Polytechn. Inst., 1970, No. 295, 15-28 (in Russian).

43. Kulbach, V. On the interaction between deformations of hanging roofs of negative curvature and displacements of the edge frame. In Research Conference "50 years of the Building Research Institute of the Technical University of Prague”. Prague, 1971, 60-70.

44. Kulbach, V. Approximate statical analysis of saddle-formed suspension roofs with deformable elliptical contour beam. Izv. vysch. uchebn. zaved. stroit. $i$ arch., 1971, No. 4, 55-61 (in Russian).

45. Kulbach, V. and Laul, H. Analysis of a cable network with negative Gaussian curvature. J. Struct. Mech. (Helsinki), 1974, 7 (1), 3-18.

46. Kulbach, V. Analysis of saddle-formed hanging roofs with regard to deformations of the contour beam. In Second National Congress on Theoretical and Applied Mechanics (Varna, 1973). 1976, 291-300 (in Russian).

47. Mänd, U. About statical behaviour of suspended networks with combined contour structures. In Proc. Conference "Thin-walled and Spatial Structures". Tallinn, 1978, $20-21$ (in Russian).

48. Hallang, T. Effects of geometrical nonlinearity of contour deformations on behaviour of saddleformed suspension structures. In Proc. Conference "Thin-walled and Spatial Structures". Tallinn, 1978, 27-28 (in Russian).

49. Talvik, A. Experimental investigation of statical behaviour of a model of the hanging roof with straight contour beams. Trans. Tallinn Polytechn. Inst., 1981, No. 504, 13-16 (in Russian).

50. Kulbach, V. and Õiger, K. Saddle-shaped suspension roofs without outward thrust. In Proc. Conference "Research, Design and Construction of suspension System for Roof and Engineering Structures”. Kiev, 1982, 154-163 (in Russian).

51. Kulbach, V. and Paane, P. Statical testing of an acoustic screen model. Trans. Tallinn Techn. Univ., 1990, No. 721, 21-31.

52. Kulbach, V. Behaviour of tubular contour of hypar-formed hanging roofs. In Tubular Structures. Elsevier Applied Science, London, New York, 1990, 437-442.

53. Kulbach, V. and Õiger, K. About the initial form of the prestressed cable network. Trans. Tallinn Polytechn Inst., 1969, No. 278, 105-118 (in Russian).

54. Laul, H. and Kulbach, V. About the choice of initial form of saddle-shaped suspension roofs with curved contour beams. Spatial Structures for Houses and Buildings. Moscow, 1977, 3, 13-23 (in Russian).

55. Engelbrecht, J. A nonlinear dynamic analysis of hanging structures. In Research Conference "50 years of Building Research Institute of the Technical University of Prague". Prague, 1971, 26-32.

56. Hendrikson, V., Õiger, K., and Talvik, I. Wind-tunnel studies of Tartu song festival complex. Trans. Tallinn Techn. Univ., 1989, No. 691, 55-62.

57. Õiger, K. and Talvik, I. Determination of dynamic characteristics of saddle-shaped suspension roof. Trans. Tallinn Techn. Univ., 1990, No. 721, 32-37.

58. Kulbach, V. Saddle-shaped prestressed networks with rigid or flexible contour structures. In Spatial Structures in New and Renovation Projects. Moscow, 1998, 2, 485-494.

59. Kulbach, V. and Engelbrecht, J. Calculation of elastic threads by method of deformation. Trans. Tallinn Polytechn. Inst., 1967, No. 256, 57-64 (in Russian).

60. Kulbach, V. Analysis of suspension roofs with doubled system of cables. Trans. Tallinn Polytechn. Inst., 1968, No. 269, 65-74 (in Russian).

61. Aare, J., Goldenberg, I., and Kulbach, V. Dependence of stresses and displacements of mast cranes upon the pretension of tiebacks. Trans. Tallinn Polytechn. Inst., 1974, No. 357, 13 20 (in Russian).

62. Aare, J., Kulbach, V., and Goldenberg, I. Design of mast cranes in consideration of system displacements. Trans. Tallinn Polytechn. Inst., 1976, No. 410, 3-10 (in Russian). 
63. Kulbach, V. Statical analysis of girder- or cable-stiffened suspended structures. Proc. Estonian Acad. Sci. Eng., 1995, 1, 2-19.

64. Kulbach, V. Half-span loading of cable structures. J. Constr. Steel Res., 1999, 49, 167-180.

65. Kulbach, V. Design of different suspension bridges. In Proc. 2nd European Conference on Steel Structures. Prague, 1999, 2, 395-398.

66. Kulbach, V. and Talvik, I. Bridge structures for the fixed link Saaremaa. In Strait Crossings 2001 (Krokeborg, J., ed.), Balkema, Lisse, 2001, 221-226.

67. Kulbach, V. and Talvik, I. Analysis of self-anchored suspension bridge in Estonia. In CableSupported Bridges - Challenging Technical Limits. IABSE Reports, Seoul, 2001, 84, 170171 (full text on the CD-ROM).

68. Kulbach, V., Idnurm, S., and Idnurm, J. Static analysis of suspension bridges loaded by concentrated forces. J. Struct. Mech. (Helsinki), 2000, 34 (2), 3-14.

69. Kulbach, V. and Lääne, A. Analysis of suspension structures with radial cables. In Proc. 6th International Conference "Modern Building Materials, Structures and Techniques". Vilnius, 1999, 208-213.

70. Kulbach, V. Computation of the stress state for different circular suspension roof structures. In Modern Building Materials, Structures and Techniques. Vilnius, Tehnika, 2001, 287-288 (full text on the CD-ROM).

71. Kulbach, V. Problems of Statical Calculation of Cable Systems. Tallinn Polytechn. Inst., Tallinn, 1970.

72. Aare, J. and Kulbach, V. Accurate and approximate analysis of statical behaviour of suspension bridges. J. Struct. Mech. (Helsinki), 1984, 17 (3), 1-12.

73. Kulbach, V. and Õiger, K. Statical Analysis of Suspension Systems. Tallinn Technical University, Tallinn, 1986 (in Russian).

74. Õiger, K. and Parts, A. Static calculation of suspended network. Trans. Tallinn Polytechn. Inst., 1987, No. 640, 3-9 (in Russian).

75. Kulbach, V. Statical behaviour of straight cables under primary and secondary cross loading. Proc. Estonian Acad. Sci. Phys. Math., 1990, 39, 278-281.

76. Kulbach, V. Hanging roofs as acoustic screens for song festival tribunes in Estonia. Trans. Tallinn Techn. Univ., 1991, No. 721, 12-20.

77. Kulbach, V. From simple plane to complicated spatial suspension structures. In Spatial Structures. Znanie, Moscow, 1991, 149-152 (in Russian).

78. Kulbach, V. Design and erection of long-span hypar-networks. In Places of Assembly and Long-Span Building Structures. IABSE Reports, Zürich, 1994, 71, 37-42.

79. Kulbach, V. A new hypar-network in Estonia. In Proc. Nordic Steel Construction Conference 95 (Malmö, Sweden, 1995). Stockholm, 1995, 2, 733-740.

80. Kulbach, V. Plane and spatial suspension structures. In Challenges to Civil and Mechanical Engineering in 2000 and Beyond. Warszawa, 1997, 3, 143-152.

81. Kulbach, V. A system of nondimensional parameters for evaluation of different cable systems. In Proc. 5th International Conference "Modern Building Materials, Structures and Techniques". Vilnius, 1997, 194-199.

82. Tärno, I. Effects of Contour Ellipticity upon Structural Behaviour of Hyparform Suspended Roofs. Licentiate Thesis. Royal Institute of Technology, Stockholm, 1998.

83. Kulbach, V. Continual analysis of suspension bridges. In 4th Euromech Solid Mechanics Conference. Book of Abstracts. Metz, 2000, 634.

84. Kulbach, V. and Kivi, E. Experimental investigation of the Saaremaa suspension bridge model. Proc. Estonian Acad. Sci. Eng., 2002, 8, 114-120. 


\title{
Eelpingestatud kaabelkonstruktsioonide uurimisest Tallinna Tehnikaülikoolis
}

\author{
Valdek Kulbach \\ On esitatud ülevaade kaabelkonstruktsioonide arengust maailmas ning nende \\ teoreetilisest ja eksperimentaalsest uurimisest Tallinna Tehnikaülikoolis. On \\ kirjeldatud olulisemaid Eestis püstitatud kaabelkonstruktsioone.
}

